\title{
Embodied Energy Comparison of Prefabricated and Conventional Building Construction
}

\author{
Sharon T. Abey ${ }^{1}$ K. B. Anand ${ }^{1}$ (1) \\ Received: 13 October 2018/Accepted: 1 August 2019/Published online: 10 August 2019 \\ (C) The Institution of Engineers (India) 2019
}

\begin{abstract}
Adoption of sustainable construction practices is of prime importance, in order to reduce resource exploitation and save for the future. Construction activities become energy intensive, due to the use of large quantities of raw materials, which need immense energy for processing them into the final product. Other factors include construction process energy and transportation energy. This study is directed to the analysis of embodied energy (EE) entailed in the construction of a residential building, using prefabricated elements and conventional in situ construction. A significant amount of energy-intensive materials, utilized in both types of construction, drain $90 \%$ of the EE. Transportation energy is the next big consumer in line, as prefab factories are likely to be situated at remote distances, unlike ready mixed concrete plants. EE expended for prefabricated construction, by deployment of energy-efficient materials and optimal construction periods, was found to be marginally $(5.7 \%)$ higher than conventional construction. The contribution of infill partition wall materials was noticeably higher in prefabricated residential buildings over commercial buildings.
\end{abstract}

Keywords Embodied energy · Prefabricated construction · Human labor energy - Construction process energy . Transportation energy

\section{K. B. Anand}

kb_anand@amrita.edu

1 Department of Civil Engineering, Amrita School of Engineering, Coimbatore, Amrita Vishwa Vidyapeetham, Coimbatore, India

\section{Introduction}

Constructions are indispensable elements that foster sustained growth of a nation, and form an integral part of civilization. Construction activities in India have increased manifolds, in the past few years, and their growth rate is expected to increase further, by 2050 , ensued by the rise in population and urbanization. Construction-related undertakings constitute $40 \%$ of global energy consumption, with India identified as among the top 10 countries that consume a major share of energy [1]. World Energy Outlook's Special Report-2015 reveals that buildings occupy second place in the energy consumption chart, after the industrial sector [2]), due to the bulk utilization of materials in all stages of construction. Major energy consumers include the manufacturing of building materials, transportation, construction process, and labor sectors. It is vitally important to have an awareness of the energy utilized, in the extant construction practices, and find ways to reduce it.

Total energy used by a building is the sum of embodied energy (EE) and operation energy (OE). EE of a building is the total energy drained for its construction, while operational energy is the cumulative energy expended over its lifetime, to ensure the security and habitability of its occupants. Assessment of the life cycle energy (LCE), by Praseeda et al. [3], has shown wide variations in the EE component (varying from 10 to $80 \%$ ). In recent times, EE computations, at the material level, have assumed paramount importance, owing to the realization of the need to optimize energy consumption.

Elements of EE include energy spent, right from the time of extraction of raw materials, through various processing stages, up to their disposal [4]. EE of a building is comprised of initial EE (IEE), recurring EE (REE), and demolition EE (DEE) [5-7]. Both the direct and indirect 
energy, spent for construction of a building, constitute the IEE. Direct energy is made up of transportation energy and construction process energy. Indirect energy is the EE of all the materials that go into the construction. Natural sources form the primary assets for materials used for construction. Subsequent to extraction, the natural resources undergo a number of energy-consuming processes, to be transformed into a finished product such as cement steel and aggregate. Volume of energy, utilized in the making of a material, depends on the adopted process of manufacture. Most energy-guzzling materials, used in the construction industry, are steel, brick, and cement [8, 9]. Adoption of industrial waste materials such as coal ash and mine waste, in construction, can bring down EE of buildings [10, 11].

Appraisal of a building's EE, restricted to computations at the material level, will not provide an accurate estimate. Transportation energy (TE), construction process energy, and labor energy must also be accounted for, to provide credible estimate of a building's EE. Frequently, these components are not factored in, as their assessment is tedious. Previous studies apropos the analysis of $\mathrm{EE}$, operational energy, life cycle energy, and life cycle assessment of a building have yielded widely varying results. Dixit et al. [12] have listed a handful of parameters that generate wide variations in the realistic estimation of EE. Differences in the geographical location, the method of analysis, the adopted system boundary, the type of building materials, and methods used for construction contribute to the variations in EE evaluation [12]. Table 1 portrays a referenced summary of previous studies in this area, during the last decade.

The above summary justifies that building materials take the major share in the computed EE value; contributions from the TE and construction process energy are minimal. Table 1 also showed that EE ranges from $1 \mathrm{GJ} / \mathrm{m}^{2}$, for load-bearing stone masonry building, up to $14 \mathrm{GJ} / \mathrm{m}^{2}$, for the prefabricated steel building.

Wide-ranging literature survey of previous attempts has emphasized the need for a fair analysis of EE, in order to identify the major processes of energy consumption, and find best possible measures to reduce it. Modern methods of construction have not yet been widely adopted in India. Conventional-type construction is still preferred to the modern techniques, constrained by requirements of capital investments and professional skill level.

Lopez-Mesa et al. [22] noted that the environmental implication of precast floors is $12.5 \%$ less than in situ cast floors. Carbon emission per cubic meter of precast concrete is $10 \%$ less than cast in situ type [23]. Lesser emission for prefabricated building implies that energy utilized or fuel consumed is minimal. Comparison of both the types of construction, by Mao et al. [24], indicated a much higher value of emission level in the conventional method. The present research is focused on comparison of EE for a conventional, and a prefabricated RCC building.

\section{Significance and Objectives of the Study}

Prefabricated buildings are not common in India, although their history can be traced back to 1950 [25]. This is due to a lack of awareness of the technology and its benefits, across the country. However, in cities, the usage of modern methods of construction have assumed crucial importance in order to reduce the mess associated with the conventional method of construction-colossal dust, pollution, and traffic congestions. Difficulties in delivering construction materials (like concrete), in a short period of time, also favor adoption of prefab construction in cities. Hence, computation of EE of prefabricated building is anticipated to gain increased significance, in India, during the coming years.

The primary objective of the study was to quantify energy consumption, in prefabricated and conventional buildings, as energy consumed per square meter of the building floor area. The conventional construction methodology varies from prefabricated construction in a number of ways, including equipment utilization and the extent of human labor involved. This calls for a comparison of energy consumption, at different stages in construction (inclusive of human labor energy) of the prefabricated and conventional construction.

In this study, the EE assessment of the conventionaltype construction assumed that ready mix concrete (RMC) was used for concrete works. During the course of this investigation, it was found that RMC plants, in India, run either with electricity or diesel power. Hence, energy consumptions, in two types of RMC plants, were compared to gauge the variation of EE per cubic meter of fresh concrete.

\section{Methodology}

Each of the stages, involved in the erection of prefabricated and conventional concrete structures, was identified, and the energy associated with each method was computed, stage-wise, and aggregated, to obtain the value of EE. Figures 1 and 2 depict different stages of energy consumption in the two methods of construction, associated with this research.

\section{System Boundary}

Level 1 and Level 2 of a four-level system boundary for EE assessment, suggested by Praseeda et al. [3], were considered for the present study. The first level includes the 
Table 1 Summary of salient studies on EE

\begin{tabular}{|c|c|c|c|}
\hline Author & Study details & System boundary & Key observations on EE \\
\hline $\begin{array}{l}\text { Macias } \\
\text { et al. } \\
\text { [13] }\end{array}$ & $\begin{array}{l}\text { LCE of residential building using cumulative } \\
\text { energy demand } \\
\text { Three different construction methods: isolated } \\
\text { concrete form, concrete load-bearing wall, } \\
\text { beam column confined masonry } \\
\text { Roofing using concrete slab and a metallic } \\
\text { alloy } \\
\text { Countries: Ecuador, the USA }\end{array}$ & $\begin{array}{l}\text { Sum of material energy (excluding } \\
\text { plumbing, electrical, and finishing } \\
\text { work) and construction energy }\end{array}$ & $\begin{array}{l}2-3.2 \mathrm{GJ} / \mathrm{m}^{2} \\
\text { Confined masonry has the lowest energy }\end{array}$ \\
\hline $\begin{array}{l}\text { Praseeda } \\
\quad \text { et al. } \\
\text { [14] }\end{array}$ & $\begin{array}{l}\text { LCE of RC residential building } \\
\text { Buildings from different climatic zones } \\
\text { Type of construction: conventional } \\
\text { Country: India }\end{array}$ & $\begin{array}{l}\text { Sum of EE of all materials used, for a } \\
\text { cubic meter of building }\end{array}$ & $\begin{array}{l}(1.01-10.51) \mathrm{GJ} / \mathrm{m}^{2} \\
\text { Correlation exists only between } \mathrm{OE} \text { and } \\
\text { the climatic zones } \\
\text { EE variation with different types of } \\
\text { building materials }\end{array}$ \\
\hline $\begin{array}{l}\text { Bansal } \\
\text { et al. } \\
{[15]}\end{array}$ & $\begin{array}{l}\text { EE of low-cost residential buildings } \\
\text { Buildings have load-bearing brick walls with } \\
\text { reinforced cement concrete (RCC) roof } \\
\text { Country: India }\end{array}$ & $\begin{array}{l}\text { Sum of EE of all materials used for a } \\
\text { cubic meter of building excluding } \\
\text { doors and windows }\end{array}$ & $\begin{array}{l}(2.092-4.257) \mathrm{GJ} / \mathrm{m}^{2} \\
\text { TE of material to site is not included }\end{array}$ \\
\hline $\begin{array}{l}\text { Ramesh } \\
\text { et al. } \\
\text { [16] }\end{array}$ & $\begin{array}{l}\text { LCE of steel reinforced concrete residential } \\
\text { building } \\
\text { Type of construction: conventional } \\
\text { Country: India }\end{array}$ & $\begin{array}{l}\text { Sum of IEE (material, construction, } \\
\text { transportation) OE, REE DEE }\end{array}$ & $\begin{array}{l}\text { IEE: } 7.35 \mathrm{GJ} / \mathrm{m}^{2} \\
\text { EE: } 11 \% \text { of total energy } \\
\text { Energy for on-site construction and } \\
\text { demolition less than } 1 \%\end{array}$ \\
\hline $\begin{array}{l}\text { Lu et al. } \\
\text { [17] }\end{array}$ & $\begin{array}{l}\text { LCE assessment of residential building using } \\
\text { input-output-based hybrid analysis } \\
\text { Building description: prefabricated steel and } \\
\text { timber building, and conventional concrete } \\
\text { building } \\
\text { Country: Australia }\end{array}$ & $\begin{array}{l}\text { Sum of material energy and capital } \\
\text { energy }\end{array}$ & $\begin{array}{l}\text { Prefabricated steel: } 14.40 \mathrm{GJ} / \mathrm{m}^{2} \\
\text { Prefabricated timber: } 10.49 \mathrm{GJ} / \mathrm{m}^{2} \\
\text { Conventional concrete: } 9.64 \mathrm{GJ} / \mathrm{m}^{2} \\
\text { EE of steel fabricated building is } 50 \% \\
\text { greater than conventional concrete } \\
\text { building }\end{array}$ \\
\hline $\begin{array}{l}\text { Jiao et al. } \\
{[18]}\end{array}$ & $\begin{array}{l}\text { EE analysis of commercial RCC building } \\
\text { Type of construction: conventional } \\
\text { Countries: China and New Zealand }\end{array}$ & $\begin{array}{l}\text { Sum of material energy and human } \\
\text { labor energy }\end{array}$ & $\begin{array}{l}\text { Up to } 5.0 \mathrm{GJ} / \mathrm{m}^{2} \\
\text { TE not included }\end{array}$ \\
\hline $\begin{array}{l}\text { Chang } \\
\text { et al. } \\
\text { [19] }\end{array}$ & $\begin{array}{l}\text { EE and emission of commercial RCC building } \\
\text { using process-based hybrid model } \\
\text { Type of construction: conventional } \\
\text { Country: China }\end{array}$ & $\begin{array}{l}\text { Sum of material energy, and energy } \\
\text { for transportation and construction }\end{array}$ & $\begin{array}{l}6.3 \mathrm{GJ} / \mathrm{m}^{2} \\
\text { Influence of TE on entire EE is } 4 \% \\
\text { Influence of construction on entire EE is } \\
6 \%\end{array}$ \\
\hline $\begin{array}{l}\text { Monahan } \\
\text { et al. } \\
\text { [20] }\end{array}$ & $\begin{array}{l}\text { Embodied carbon and energy of residential } \\
\text { building based on three types of materials } \\
\text { used for construction } \\
\text { Modern method of construction (MMC): } \\
\text { prefabricated building } \\
\text { Country: UK }\end{array}$ & $\begin{array}{l}\text { Sum of material energy, energy for } \\
\text { transportation, manufacturing, and } \\
\text { construction }\end{array}$ & $\begin{array}{l}5.7-8.2 \mathrm{GJ} / \mathrm{m}^{2} \\
\text { Use of timber resulted in low EE and } \\
\text { carbon emission }\end{array}$ \\
\hline $\begin{array}{l}\text { Adalberth } \\
\text { [21] }\end{array}$ & $\begin{array}{l}\text { LCE of prefabricated residential building } \\
\text { Prefabricated materials: wooden frames, } \\
\text { factory-made concrete walls and joist } \\
\text { Insulating material: glass wool, concrete } \\
\text { roofing tiles } \\
\text { Country: Sweden }\end{array}$ & $\begin{array}{l}\text { Sum of material energy, and energy } \\
\text { for production, transportation, } \\
\text { maintenance and destruction }\end{array}$ & $\begin{array}{l}\mathrm{EE}+\mathrm{OE} \text { range: }(27.4-31.7) \mathrm{GJ} / \mathrm{m}^{2} \\
\mathrm{TE} \text { and process energy constitute } 1 \% \text { of } \\
\text { total energy used } 15 \% \text { of } \mathrm{EE} \text { for } \\
\text { manufacturing construction materials }\end{array}$ \\
\hline $\begin{array}{l}\text { Debnath } \\
\text { et al. [8] }\end{array}$ & $\begin{array}{l}\text { Energy analysis of reinforced concrete } \\
\text { residential building } \\
\text { Type of construction: conventional method } \\
\text { Country: India }\end{array}$ & $\begin{array}{l}\text { Material energy (considering only } \\
\text { major building materials used for } \\
\text { construction) }\end{array}$ & $\begin{array}{l}(3-5) \mathrm{GJ} / \mathrm{m}^{2} \\
\text { Major energy contributors are bricks, } \\
\text { cement, and steel }\end{array}$ \\
\hline
\end{tabular}




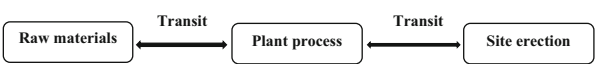

Fig. 1 Stages of energy consumption in a prefabricated building

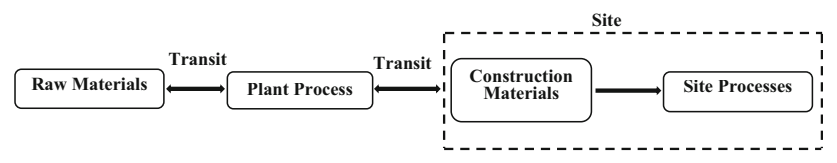

Fig. 2 Stages of energy consumption in a conventional building

direct energy consumption in the production process. Level 2 represents the energy consumed in extraction of raw materials, its transportation, and procurement of energy sources for level 1 .
For precast elements, the sum of EE of all materials, transportation energy, process energy in precast plant, and erection energy per cubic meter of RCC was calculated. In the case of the conventional building, concrete placement energy and compaction energy were considered instead of erection energy. In conjunction with the two-level system boundary, human labor energy, associated with both the types of construction, was also included.

\section{Human Labor Energy}

The debate on inclusion of human labor energy in the computations of EE remains an unsettled issue [12]. Nonetheless, for a more comprehensive analysis, human labor energy was considered in this study. The quantity of human labor, utilized for prefabricated and conventional

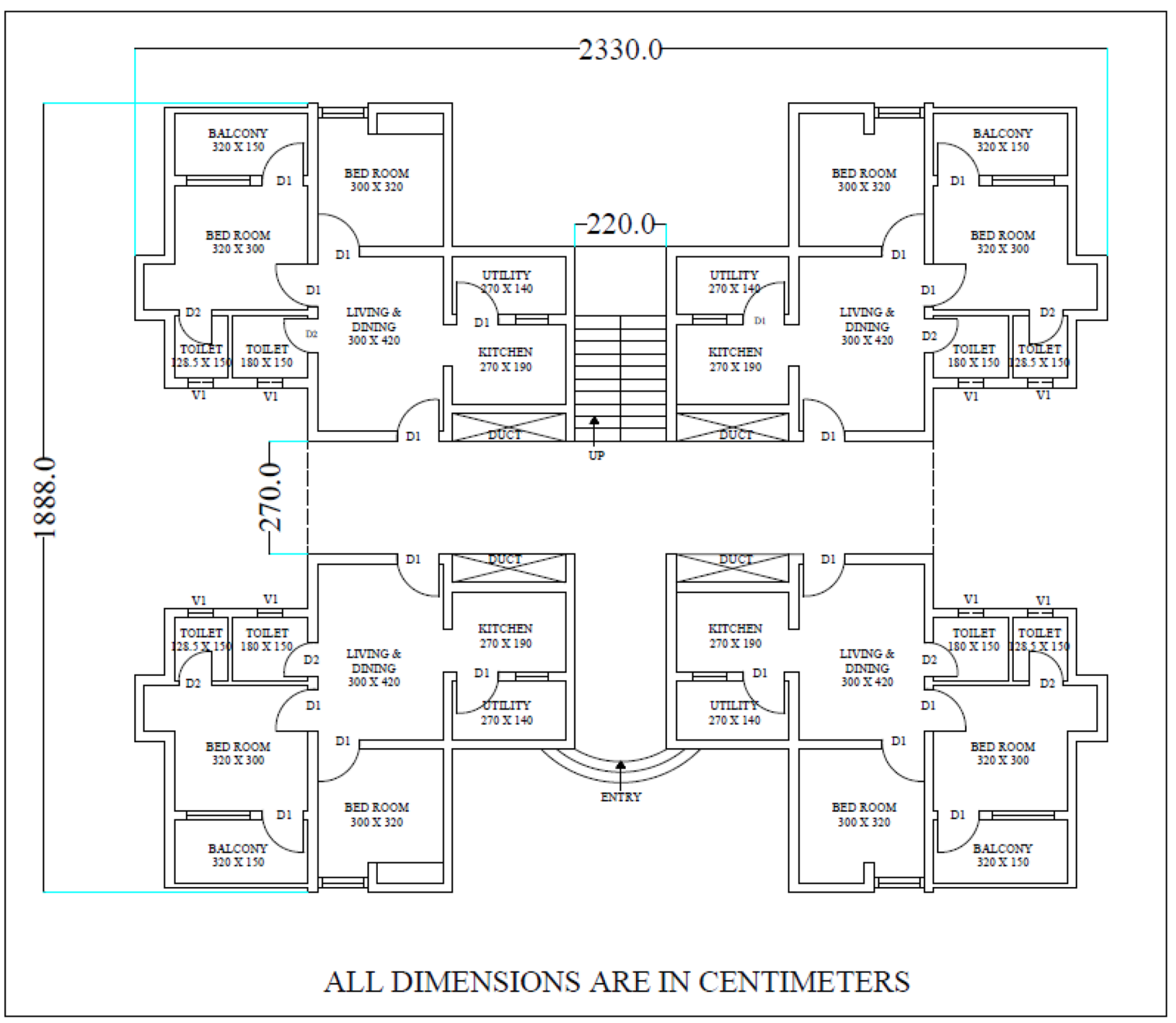

Fig. 3 Typical floor plan with details of apartment 
Table 2 Details of prefabricated residential building

\begin{tabular}{lll}
\hline General & Measurements & Specifications \\
\hline $\begin{array}{l}\text { Type of building: RCC, residential: } 4 \\
\text { floors }\end{array}$ & $\begin{array}{c}\text { Carpet area of each apartment } \\
\text { unit: } 45.5 \mathrm{~m}^{2}\end{array}$ & $\begin{array}{c}\text { Precast elements used in the building: wall panel, beam, column, } \\
\text { solid slab, staircase, and sunshade } \\
\text { Number of apartments per floor: } 4 \\
\text { Floor area of each floor: } 232 \mathrm{~m}^{2} \\
\text { Grade of precast elements: M40 }\end{array}$ \\
$\begin{array}{c}\text { Total floor area of building: } \\
928 \mathrm{~m}^{2}\end{array}$ & $\begin{array}{c}\text { Foundation work: } 143 \mathrm{~m}^{3} \text { of conventional in situ construction using } \\
\text { M30 grade of concrete }\end{array}$ \\
$\begin{array}{ll}\text { Distance from precast plant to site: } \\
\text { Volume of RCC elements in the } \\
\text { building: } 571 \mathrm{~m}^{3}\end{array}$ \\
$\begin{array}{ll}\text { Distance between RMC plant and site: } \\
34 \mathrm{~km} \text { (one way) }\end{array}$ & \\
\hline
\end{tabular}

construction methods, shows wide variation. The significance of including human labor energy in EE calculation was propounded by Dixit et al. [5], Jiao et al. [18], Pulselli et al. [26], and Langston et al. [27]. With regard to construction materials, the contribution of human labor energy was estimated to be in the range of $1-14 \%$ of the composite EE. Its share becomes more prominent for buildings, in countries like India and China, where human labor, available in plenty, is frequently resorted to, in the construction sector [5].

The method applied in this study is adopted from the United Nations' Food and Agriculture Organization's (FAO) Report on Human Energy Requirements-2001 [28]. Total energy expenditure (TEE) in MJ/day for an individual is the product of basal metabolic rate (BMR) in $\mathrm{MJ} /$ day and physical activity level number (PAL). BMR is calculated based on age, weight $(\mathrm{Wt})$, and gender of the individual.

$\mathrm{TEE}=\mathrm{BMR} \times \mathrm{PAL}$

$\mathrm{BMR}=0.063$

$$
\times(\mathrm{Wt}+2.896) \text { for males, age }(18-30) \text { years }
$$

$\mathrm{BMR}=0.048$

$$
\times(\mathrm{Wt}+2.896) \text { for males, age }(30-60) \text { years }
$$

PAL depends on the type of activity the individual is engaged in-light, moderate, or vigorous activity. Application of the PAL factor for construction work was also reported in an earlier study [5]. PAL factors were considered only for males engaged in moderate activities (1.99) and vigorous activities (2.4), given that light activity labor is negligible in the construction sector. In this investigation, two age groups were considered: 18-30 years and 30-60 years, under the assumption that the major workforce would fall among these age groups. Details on the number of laborers, used at different stages of construction, were collected for both the conventional and prefab construction. PAL, for different categories [28] of labor, was determined by accounting for the physical effort involved in a specific task.

\section{Details of Study}

To compute the energy associated with prefab construction, a fully prefabricated residential building, situated in Coimbatore, Tamil Nadu, India, was chosen as a test case, details of which are given in Fig. 3 and Table 2.

EE calculations, for conventional-type construction, were also performed, for the same building plan shown in Fig. 3. However, the requisite data were collected from a conventional building project, with comparable floor area

\begin{tabular}{|c|c|c|c|c|c|}
\hline Description & Cement & Fine aggregate & Coarse aggregate & Supplementary material & Steel \\
\hline EE coefficient of materials $(\mathrm{MJ} / \mathrm{kg})$ & 4.32 & 0.06 & 0.04 & 0 & 34.23 \\
\hline Quantity for $1 \mathrm{~m}^{3}$ concrete $\left(\mathrm{kg} / \mathrm{m}^{3}\right)$ & 430 & 680 & 1200 & 50 & 113.65 \\
\hline EE of materials $\left(\mathrm{MJ} / \mathrm{m}^{3}\right)$ & 1857.6 & 42.2 & 48.0 & 0 & 3890.24 \\
\hline Fuel to move $1 \mathrm{~kg}$ of material & 0.003 & 0.001 & 0.001 & 0.003 & 0.001 \\
\hline Fuel $^{\mathrm{a}}$ in liters (per $\mathrm{m}^{3}$ of concrete) & 1.32 & 0.40 & 0.71 & 0.16 & 0.11 \\
\hline Transportation energy $\left(\mathrm{MJ} / \mathrm{m}^{3}\right)$ & 49.97 & 15.14 & 26.95 & 6.10 & 4.20 \\
\hline
\end{tabular}

Table 3 Transportation and EE of raw materials

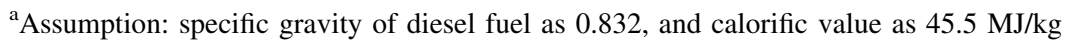


Table 4 Energy utilized per cubic meter of precast RCC components

\begin{tabular}{llll}
\hline Description & Plant process & Precast transportation & Erection (crane) \\
\hline Fuel ${ }^{\mathrm{a}}$ power & $15 \mathrm{kWh} / \mathrm{m}^{3}$ & $7.1 \mathrm{1} / \mathrm{m}^{3}$ & $3.51 / \mathrm{m}^{3}$ \\
Energy & $54.0 \mathrm{MJ} / \mathrm{m}^{3}$ & $268.81 \mathrm{MJ} / \mathrm{m}^{3}$ & $132.49 \mathrm{MJ} / \mathrm{m}^{3}$ \\
\hline
\end{tabular}

${ }^{\mathrm{a}}$ Considering specific gravity of diesel fuel as 0.832 and calorific value as $45.5 \mathrm{MJ} / \mathrm{kg}$

and building height. The grade of concrete used, in the types of construction investigated herein, was different, as prefabricated elements need higher strength, to withstand extra such as handling and erection stresses. The commonly used grade of concrete, for the conventional-type construction, is M20 or M30, unless specified otherwise by the clients. Brick masonry infill walls are generally used for conventional-type construction, whereas RCC panel walls were adopted for the prefabricated building considered in the study. The total volume of RCC used in superstructure of conventional building was assumed to be the total volume of RCC in the prefabricated building less the volume of infill walls, which equaled $210 \mathrm{~m}^{3}$.

For superstructure and substructure of conventional residential building, grades of concrete were assumed as $\mathrm{M} 30$ and M25, respectively, and brick masonry for the infill walls. Quantity of infill brick masonry was deduced, by assuming $23-\mathrm{cm}$-thick ( 9 in.) exterior wall and $11.5-\mathrm{cm}$ thick (4.5 in.) interior partition wall. The labor hours, entailed at different stages of construction, were collected through project plant and site surveys.

\section{Data Collection}

A separate questionnaire was prepared for both the methods of construction. For prefabricated building, data were collected, from the prefabrication plant, and on-site. Details of labor used in different stages, the energy required for running the plant, and the capacity of erection crane were collected (from the precast plant as well as from site) for energy analysis. Tables 15 and 16 (Appendix) summarize the data collected for the prefabricated and conventional construction, respectively.

\section{Results and Discussion}

Prefabricated building construction is an emerging construction method all set to prevail over conventional methods. Quantification of total energy utilized, for these two types of construction methods, is inescapable, when we need to select between them.

\section{Prefabricated Construction}

In case of the prefabricated construction, different building elements are cast in the prefab factory, where most of the processes are automated and consume energy. In the factory, different stages of energy consumption are transit energy required for raw material procurement, plant process energy, and human labor energy. Process in the factory includes reinforcement work, formwork, concreting, and loading the elements into haulage trucks.

\section{Transportation and Material Energy}

As the minimum grade of concrete, for prefabricated building components is M40, calculation of materials was done accordingly. Table 3 shows the calculations of transportation energy and material energy. Details of the distance between the material sources and the prefab factory, as well as the capacity and mileage of trucks that carry them, were collected and compiled (Appendix: Table 15). From these results, fuel required, for transportation per $\mathrm{kg}$ of material, was estimated, and summarized in Table 3. Embodied energy (EE) coefficients of materials (per unit measure) were adapted, from an earlier study by Praseeda et al. [3], for the Indian context.

Table 5 Human labor energy at prefab factory

\begin{tabular}{llll}
\hline Type of PAL & Moderate activity & & Vigorous activity \\
\hline Age group (in years) & $18-30$ & $30-60$ & $18-30$ \\
Number of laborers (per $\mathrm{m}^{3}$ of RCC) & 1 & 1 & 1 \\
BMR (MJ/day) & 6.991 & 7.013 & 6.991 \\
PAL (number) & 1.99 & 1.99 & 2.4 \\
TEE (MJ/day) & 13.91 & 13.96 & 16.78 \\
Total energy (for $1 \mathrm{~m}^{3}$ of RCC elements) & $61.48 \mathrm{MJ} / \mathrm{m}^{3}$ & & 2.4 \\
\hline
\end{tabular}


Table 6 Human labor energy at prefab project site

\begin{tabular}{lll}
\hline Type of PAL & Moderate activity & \\
\hline Age group & $18-30$ & $30-60$ \\
Number of laborers & $6 /$ day & $5 /$ day \\
BMR & 6.99 & 7.013 \\
PAL & 1.99 & 1.99 \\
TEE & $13.9 \mathrm{MJ} /$ day & $13.96 \mathrm{MJ} /$ day \\
Total energy & $153.2 \mathrm{MJ} / \mathrm{day}$ & \\
Total energy for $1 \mathrm{~m}^{3}$ & $3.43 \mathrm{MJ} / \mathrm{m}^{3}$ & \\
$\quad$ & & \\
\hline
\end{tabular}

The results in Table 3 show that material EE is generally higher than the TE; steel and cement account for the larger portion of EE of RCC. At the project site, screed concreting of $16 \mathrm{~mm}$ thickness was leveled over the floor slabs; this required an additional $4 \mathrm{~kg}$ of steel per square meter of the floor area. This resulted in an addition of $140 \mathrm{MJ} / \mathrm{m}^{3}$ to the total EE, calculated in Table 3 .

\section{Energy in Plant Process, Transportation and Erection} of elements

The processes in the prefabrication factory are discussed in an earlier section. Electricity was used for all the operations in the factory, including loading of the precast elements on to trucks. The plant process consumed $1500 \mathrm{kWh}$ units of energy per day, for the production of $100 \mathrm{~m}^{3} \mathrm{RCC}$ component per day. Table 4 shows details of the three stages-precast factory process, transportation, and erection energy, derived from Table 15.

The results in Table 4 highlight the significance of including precast transportation energy in the energy analysis. In the Indian context, transportation energy requirement is found to be large, as the number of prefabrication factories are very few in number and situated remote from project sites.

\section{Human Labor Energy}

Human labor required, for construction of prefabs, is notably less, when compared to the conventional method, as most of the work in the prefab factory is automated. Calculations of Human Labor Energy, for production of prefabricated components at the factory, and during the erection/construction process at the site are shown in Tables 5 and 6 , respectively. The labor energy component is more at the factory where human element is involved at different stages for preparations of reinforcement and formwork, concrete finishing, curing, and further processing till stockyard. In contrast, many of the processes at site during erection/construction are mechanized with much

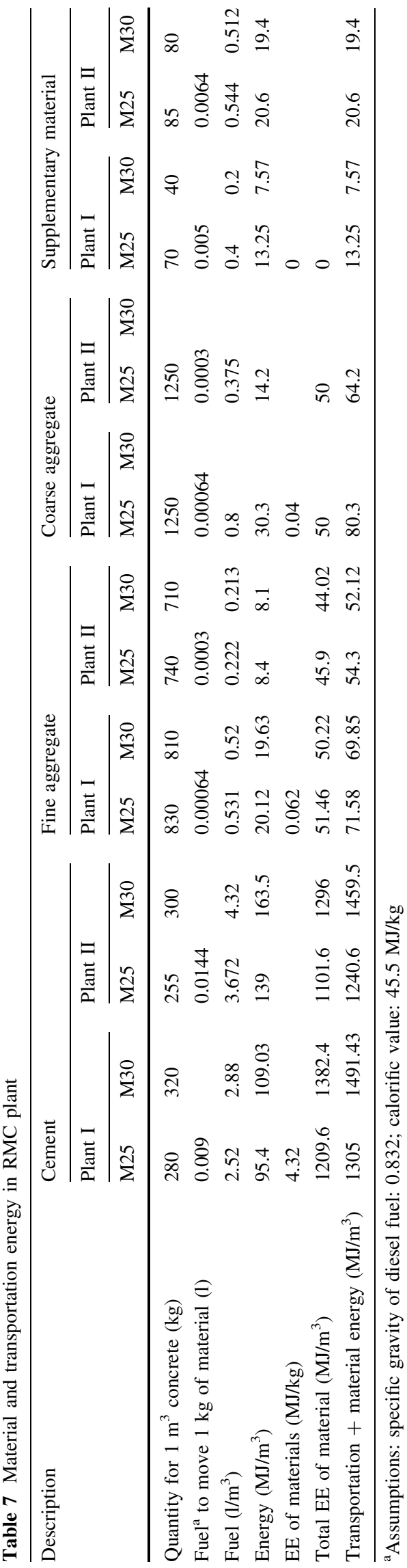


reduced human involvement, and hence have a much lesser human energy component than that necessary at the prefab factory.

In the precast manufacturing plant, 400 labor days were required to manufacture $100 \mathrm{~m}^{3}$ of precast RCC components. For the precast building considered in this study, a total of $571 \mathrm{~m}^{3}$ of prefabricated RCC was used (Table 2). From Tables 5 and 6, the total human labor energy, required for prefabricated work, was estimated as $0.04 \mathrm{GJ} /$ $\mathrm{m}^{2}$ of floor area.

\section{Conventional Construction}

\section{EE of RMC}

Conventional method of construction is the preferred method in India (albeit not desirable for cities), where the use of RMC is widespread. As a consequence, the number of RMC plants has increased in city suburbs; the RMC plants differ in many aspects such as size, capacity, age, mode of operation, and type of mixer. The two RMC plants, considered for this research, differed in their mode of operation, capacity, and age. RMC Plant (I) has a production capacity of $30 \mathrm{~m}^{3} / \mathrm{h}$, utilizes electric power, and is 18 years old. The 2-year-old Plant (II) has a capacity of producing $20 \mathrm{~m}^{3} / \mathrm{h}$, and operates with diesel fuel. Table 7 shows the calculation details of materials, and transportation energy requirements, in the RMC plants.

The results show that transportation and material energy, associated with Plant I, are slightly higher than Plant II. This variation is mainly because of two reasons:

Table 8 Plant process energy

\begin{tabular}{llllll}
\hline Process & \multicolumn{2}{l}{ Power/fuel $^{\mathrm{a}}$ consumed } & & \multicolumn{2}{l}{ Energy consumed $\left(\mathrm{MJ} / \mathrm{m}^{3}\right)$} \\
\cline { 2 - 3 } \cline { 5 - 6 } & Plant I & Plant II & & Plant I & Plant II \\
\hline Plant & $2.75 \mathrm{kWh}$ & $0.841 / \mathrm{m}^{3}$ & & 30.9 & 31.8 \\
Loader & $0.16 \mathrm{l} / \mathrm{m}^{3}$ & & 6.1 & \\
\hline
\end{tabular}

aAsumptions: specific gravity of diesel: 0.832 calorific value: $45.5 \mathrm{MJ} / \mathrm{kg}$

Table 9 Human labor energy

\begin{tabular}{|c|c|c|c|c|c|c|c|c|}
\hline \multirow{3}{*}{$\begin{array}{l}\text { Type of PAL } \\
\text { Age group (in years) }\end{array}$} & \multicolumn{4}{|c|}{ Moderate activity } & \multicolumn{4}{|c|}{ Vigorous activity } \\
\hline & \multicolumn{2}{|l|}{ Plant I } & \multicolumn{2}{|l|}{ Plant II } & \multicolumn{2}{|l|}{ Plant I } & \multicolumn{2}{|l|}{ Plant II } \\
\hline & $18-30$ & $30-60$ & $18-30$ & $30-60$ & $18-30$ & $30-60$ & $18-30$ & $30-60$ \\
\hline Number of laborers (per day) & 9 & 9 & 4 & 4 & 15 & 15 & 10 & 10 \\
\hline BMR (MJ/day) & 6.991 & 7.013 & 9.991 & 7.013 & 6.991 & 7.013 & 6.991 & 7.013 \\
\hline PAL (number) & 1.99 & & & & 2.4 & & & \\
\hline TEE (MJ/day) & 125.21 & 125.64 & 55.65 & 55.84 & 251.70 & 252.47 & 167.80 & 168.30 \\
\hline
\end{tabular}

(1) the transit distance between raw material source and the site was different for each plant; (2) quantity of materials used for the same grade of concrete was different for each plant. The difference in the mileage of trucks, used in the plants, differed primarily by its size, engine capacity, and age. Plant process energies of both the plants are shown in Table 8 .

Plant II showed only $2.9 \%$ higher plant process energy than Plant I, which in spite of older age, has consumed much lower energy per unit production. Results of the human labor energy calculations are shown in Table 9. The number of laborers used in Plant II was less than Plant 1, due to the difference in capacities of the plants.

Computed values of human labor energy of Plant I and Plant II were $3.02 \mathrm{MJ} / \mathrm{m}^{3}$ and $2.56 \mathrm{MJ} / \mathrm{m}^{3}$, respectively. Figure $4 \mathrm{a}$, b shows the EE components (in \%) for Plant I and Plant II. The influence of the human labor component varied from 21.5 to $33.4 \%$ (per unit volume of concrete produced), which highlights the significance of computing human labor energy.

Materials bear a major share of the EE, due to the use of cement, which is the most energy-intensive material. The contribution of material energy varied between higher and lower grades of concrete, due to the change in cement content. Total transportation energy constituent, in RMC, ranged from 7.14 to $9.77 \%$, which shows its relevance in EE computations. Process energies of the two plants were comparable, even though they differed in their modes of operation.

\section{Construction Site-Level EE}

The site-level energy analysis included transportation energy of RMC from plant to site, energy for pumping and compaction of concrete, the EE of materials used at the site, and human labor energy involved in various site works. Energies, expended for transit of concrete to the site, pumping, and compaction of concrete, are shown in Table 10.

Motor and vibrator, deployed for pumping and compaction of concrete, used diesel as fuel for their operations. 
Fig. 4 Details of EE components for the two plants

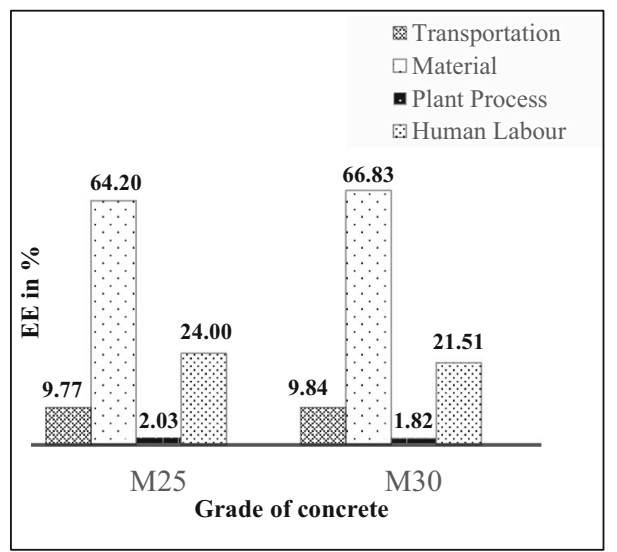

(a) Plant I

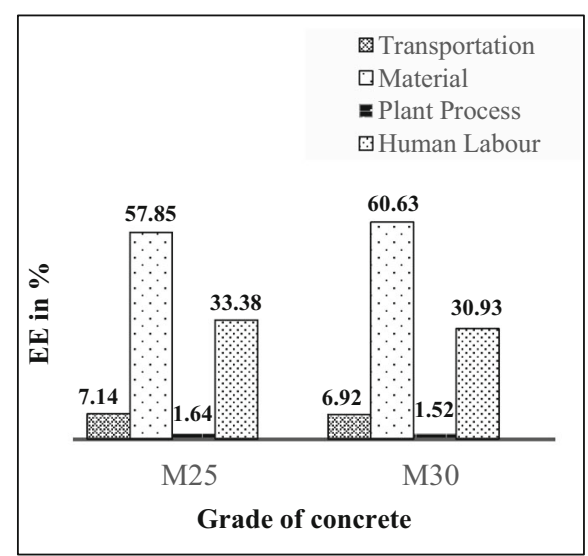

(b) Plant II
Table 10 Transit and site process energy for concrete

\begin{tabular}{lc}
\hline Stages of energy consumption & Embodied energy $\left(\mathrm{MJ} / \mathrm{m}^{3}\right)$ \\
\hline Transportation of concrete & 160.1 \\
Placing concrete & 15.14 \\
Compaction & 3.38 \\
\hline
\end{tabular}

Table 11 Energy analysis of materials used at the site

\begin{tabular}{lccl}
\hline Material & Quantity $\left(\mathrm{kg} / \mathrm{m}^{3}\right)$ & EE $(\mathrm{MJ} / \mathrm{kg})^{\mathrm{a}}$ & Total EE $\left(\mathrm{MJ} / \mathrm{m}^{3}\right)$ \\
\hline Steel & 124 & 34.23 & 4244.52 \\
Brick & 1750 & 2.42 & 4235 \\
Cement & 132 & 4.32 & 572.05 \\
Sand & 2118 & 0.04 & 84.72 \\
\hline
\end{tabular}

${ }^{\text {a }}$ Source: Praseeda et al. [3]

The energy required for compaction was very low, as compared to energy spent for pumping and transportation. Transportation energy consumed is very high compared to the energy spent on pumping and placing.

In addition to RMC, other materials were also used at the construction site. These include wire-cut bricks and cement mortar for masonry infill, as well as finishing mortar. At the site level, the total material energy of bricks, cement, and sand was computed, as given in Table 11.

From Table 11, steel, brick, and cement are conspicuous as being the major consumers of energy in the construction of conventional buildings, due to their high $\mathrm{EE}$ value.

\section{Human Labor Energy}

Generally, the number of days, during which laborers are required, is particularly more in the conventional-type construction than a prefabricated building. Use of equipment (pump for placement of concrete, concrete vibrators for compaction) in the conventional method is the current
Table 12 Human labor energy at conventional project site

\begin{tabular}{lllll}
\hline Type of PAL & \multicolumn{2}{l}{ Moderate activity } & \multicolumn{2}{l}{ Vigorous activity } \\
\hline Age group (in years) & $18-30$ & $30-60$ & $18-30$ & $30-60$ \\
Number of laborers (per day) & 1 & 1 & 10 & 10 \\
BMR (MJ/day) & 6.991 & 7.013 & 6.991 & 7.013 \\
PAL (number) & 1.99 & 1.99 & 2.4 & 2.4 \\
TEE (MJ/day) & 13.912 & 13.96 & 16.78 & 16.83 \\
Total Energy & $363.97 \mathrm{MJ} /$ day & & \\
\hline
\end{tabular}

Table 13 Foundation EE of the prefabricated building

\begin{tabular}{lll}
\hline $\begin{array}{l}\text { Stages of energy } \\
\text { consumption }\end{array}$ & $\begin{array}{l}\text { Embodied energy } \\
\left(\mathrm{MJ} / \mathrm{m}^{3}\right)\end{array}$ & $\begin{array}{l}\text { Total embodied energy } \\
\left(\mathrm{GJ} / \mathrm{m}^{2} \text { of floor area }\right)\end{array}$ \\
\hline $\begin{array}{l}\text { Embodied energy } \\
\text { RMC + placing }\end{array}$ & 1706.54 & 0.87 \\
$\begin{array}{l}\text { Transportation } \\
\text { (material) }\end{array}$ & 160.1 & \\
Compaction & 3.38 & \\
Steel (material) & 3741.1 & \\
Labor & 19.7 & \\
\hline
\end{tabular}

trend aimed at reducing the number of labor days. Computation of the Human Labor Energy, for the site, is shown in Table 12.

Laborers for excavation, leveling, shuttering work, concreting, de-shuttering, curing, bar bending, and compaction were accounted for, in this investigation. Human labor energy alone constituted $0.1 \mathrm{GJ} / \mathrm{m}^{2}$ of floor area, which is considerably high. Hence, it is of vital importance to factor in human labor energy, in the case of conventional construction.

\section{Embodied Energy in Foundation}

RCC foundation of the prefabricated building was laid out, using conventional methods, with M30 RMC. EE 
Table 14 EE of prefabricated and conventional building

\begin{tabular}{lrr}
\hline Components & EE prefabricated building (MJ) & EE conventional building (MJ) \\
\hline Total transportation & $267,978.15$ & $115,956.10$ \\
Total material & $4,229,616.10$ & $3,502,610.57$ \\
Plant process & $32,524.07$ & $13,046.20$ \\
Site process & $78,858.17$ & 6530.20 \\
Human labor & $40,303.52$ & $93,964.90$ \\
Total EE & $4,649,280.01$ & $3,732,107.97$ \\
Total EE per unit & 5.01 & 4.02 \\
Floor area $\left(\mathrm{GJ} / \mathrm{m}^{2}\right)$ & &
\end{tabular}

Fig. 5 EE energy distribution of buildings a prefabricated and b conventional

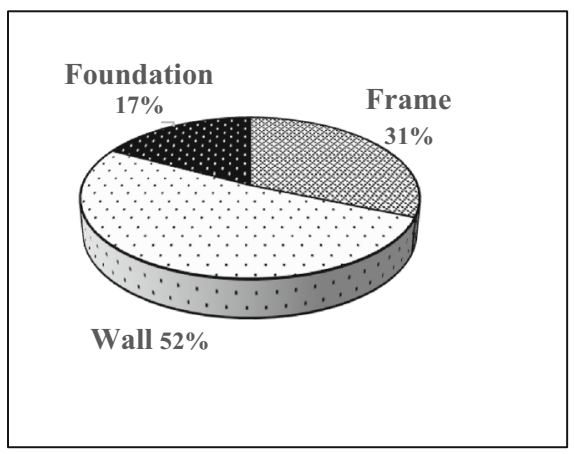

(a)

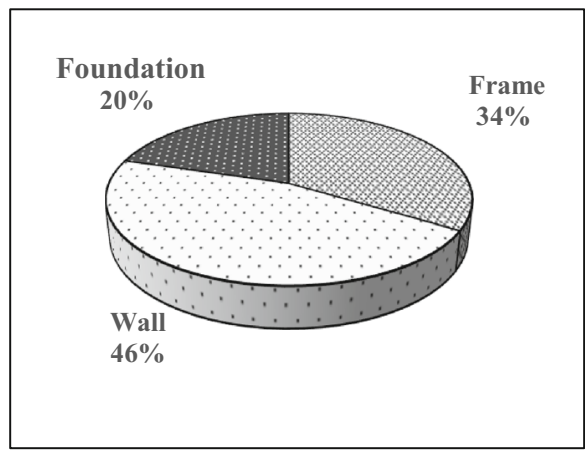

(b) estimation of the foundation was accomplished from the following components: EE of the M30 RMC and computation of the total energy required at the site. Energy expended for transit of RMC to site, pumping, and compaction of concrete was assumed to be the same as in Table 10 (for conventional building). Table 13 shows the energy incurred for different components.

\section{Comparison of Total EE of Prefab and Conventional Construction}

EE of the buildings, in the study, is the sum total of transportation, material, plant process, site process, and human labor. EEs of the prefabricated building and conventional building, calculated separately, were deduced from the cumulative of the results presented in Tables 313. Table 14 shows the different components of EE calculated and the total EE.

Figure $5 \mathrm{a}, \mathrm{b}$ shows the percentage shares of contributions to the EE, from RCC frame, foundation, and infill wall, for the prefabricated and conventional residential buildings. Among these three, infill wall consumed the major share of EE in both types of construction. The EE per unit floor area was higher for prefabricated building due to the assumption of RCC walls panels, whereas brick infill was assumed for the conventional building. Though

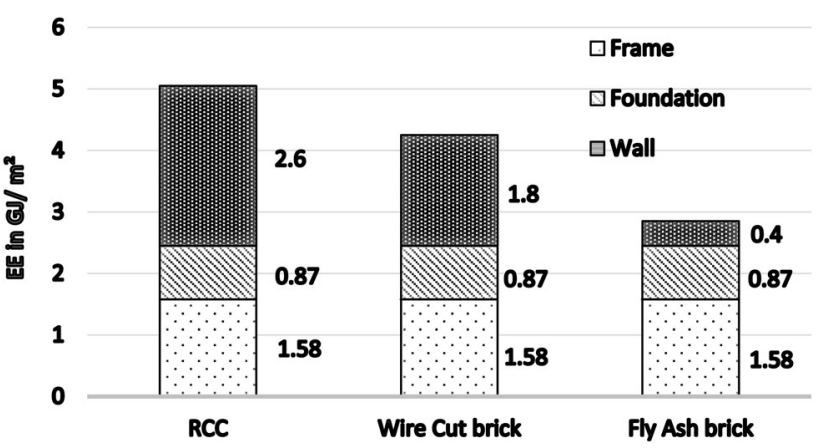

Fig. 6 EE of prefabricated building with different wall infills

the use of RCC walls can accelerate the construction, they are energy intensive compared to the brick walls.

Figure 6 shows the impact of different walling systems on EE in prefabricated buildings. The embodied energy per square meter of floor area with RCC wall, wire-cut brick wall, and fly ash brick wall were $5.01 \mathrm{GJ} / \mathrm{m}^{2}, 4.25 \mathrm{GJ} / \mathrm{m}^{2}$, and $2.85 \mathrm{GJ} / \mathrm{m}^{2}$, respectively. The building EE, adopting brick infill walls, of conventional $\left(4.02 \mathrm{GJ} / \mathrm{m}^{2}\right)$ and prefabricated $\left(4.25 \mathrm{GJ} / \mathrm{m}^{2}\right)$ construction option, was comparable. Usage of wire-cut bricks, instead of RCC walls, can reduce the total $\mathrm{EE}$ of the building by $15 \%$. Furthermore, use of fly ash bricks can reduce the total EE of the building 
Fig. 7 Comparison of building EE with RC infill wall for $\mathbf{a}$ residential and $\mathbf{b}$ commercial

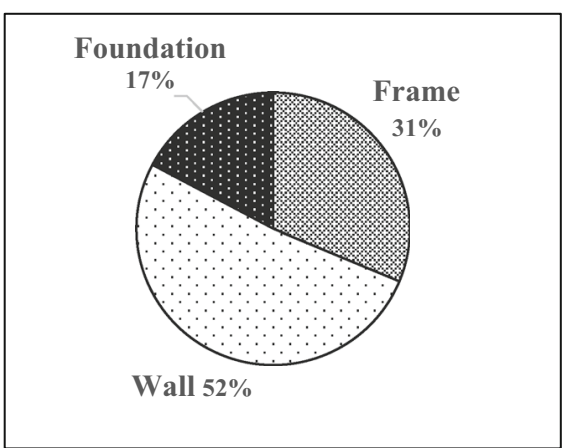

(a) Residential

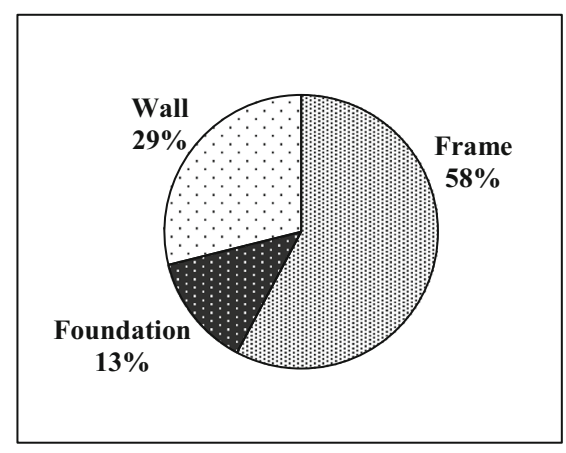

(b) Commercial by at least $40 \%$. However, precast RCC infill walls prove to be beneficial to meet a client's preferences like faster delivery of the completed building, and other functional requirements.

The effect of infill wall on building EE assumes greater significance as the quantities of infill wall, in residential, and commercial categories, vary widely. Partition walls are almost absent in commercial buildings. Based on a preliminary assessment in the surrounding areas, it was observed that the volume of the wall $\left(\mathrm{m}^{3}\right)$ per unit floor area $\left(\mathrm{m}^{2}\right)$ ranges between 0.35 and 0.4 , for residential buildings, and 0.16 and 0.2 , for commercial buildings. The higher ratio indirectly confirms the likelihood of higher EE for residential buildings. A comparison of EE components for typical buildings in the residential and commercial categories is shown in Fig. 7.

Comparing Fig. 7a, b, it is apparent that the effect of infill wall on the total EE of the commercial building is less than that of the frame, whereas it is quite the reverse in the case of residential buildings. As the quantities infilled walls are generally smaller in commercial buildings, the prefabricated construction could be more beneficial with respect to $\mathrm{EE}$.

\section{Conclusion}

EE of fresh concrete from two RMC plants, with distinct modes of operation, was found to be comparable, though they differed in size, capacity, and age. With the EE analysis of RMC, the significance of including human labor and transportation components of energy is self-evident. Human labor energy was found as high as $33.38 \%$ and transportation energy at $9.8 \%$.

Of the total EE calculated for two types of building construction, material energy has the major share. The share of materials was about $90 \%$ in EE of the building. Transportation energy constituted $5 \%$ and $3 \%$ of the total $\mathrm{EE}$, for the prefabricated and conventional building constructions, respectively. The extent of transportation energy varies, depending on the distance between the precast plant and site. Plant process energy of the prefabricated building was noted at $2.2 \%$ of total $\mathrm{EE}$, while for the conventional building, it was $1.6 \%$. Human labor energy is the third energy-intensive component in the conventional-type construction, with $2.5 \%$ and $0.86 \%$ for prefab. The infill walls contributed to a large extent in the total building EE. The building EE of conventional $\left(4.02 \mathrm{GJ} / \mathrm{m}^{2}\right)$ was as good as prefabricated $\left(4.25 \mathrm{GJ} / \mathrm{m}^{2}\right)$ construction, adopting brick infill walls (a marginal difference of 5.7\%). Prefabricated construction may very well be energy-efficient for commercial buildings, as they generally have lesser infill walls.

Funding This research did not receive any specific grant from funding agencies in the public, commercial or not-for-profit sectors.

\section{Appendix}

See Tables 15 and 16. 
Table 15 Consolidated data of prefabricated building

1. Prefabrication factory

Location

Capacity

Average daily production

Electricity consumption

1.1 Materials

Raw materials

Grade of concrete

Mix proportion

Average reinforcement $/ \mathrm{m}^{3}$

1.2 Transit: mileage $(\mathrm{km} / \mathrm{l})$, distance $(\mathrm{km})$, capacity of truck $(\mathrm{t})$

Cement

M-Sand

Aggregate

Supplementary material

1.3 Maintenance

Mode of cleaning

Process of cleaning plant and wastewater disposal

1.4 Waste management

Disposal of waste generated in the plant

1.5 Human laborers

For 1 cubic meter of precast

2. Site

2.1 General

Location of building

Type of building

Number of floors

Floor area of one level

Start and end date of project

2.2 Transit: mileage $(\mathrm{km} / \mathrm{l})$, distance $(\mathrm{km})$, capacity of truck $(\mathrm{t})$

Prefabricated elements

Distance between precast storage and site

2.3 Precast quantity $\left(\mathrm{m}^{3}\right)$

Beam

Column

Wall

Solid slab

Staircase

Sunshade

2.4 Erection

Erection steel

Average capacity of crane

Average fuel consumed

Average quantity of precast erected/day

2.5 Waste management

Disposal of waste generated in site and its disposal

2.6 Human laborers (per $8 \mathrm{~h}$ shift)

Skilled laborers

Site engineers

Crane operators
Tirupur District, Tamil Nadu, India

$150 \mathrm{~m}^{3}$

$100 \mathrm{~m}^{3}$

$1500 \mathrm{kWh} /$ day

Cement, M-Sand, aggregates, water, admixtures M40

$1: 1.58: 2.8$

$152 \mathrm{~kg}$

$5.5,212,25$

$7.5,25,18$

$7.5,25,18$

$5.5,222,25$

Human labor

Water used, reused after treatment.

Steel scrap: sold

Hardened concrete: crushed and used as aggregate

4 Nos $\times 8 \mathrm{~h}=32$ labor hours

Coimbatore, Tamil Nadu, India

Residential, RCC

4

$232 \mathrm{~m}^{2}$

22-10-2017 to $15-11-2017$

$3,110,26$

Nil

51.6

27.93

361.27

116.53

8.1

5.5

$127 \mathrm{~kg} / \mathrm{m}^{3}$

$78.33 \mathrm{t}$

$5.5 \mathrm{l} / \mathrm{h}$

70 elements

No waste generated

7

2

2 
Table 16 Consolidated data of conventional building

\section{RMC plant \\ 1.1 General \\ Location \\ Capacity \\ Average daily production \\ Electricity consumption}

\begin{tabular}{|c|c|}
\hline Main raw materials used in plant & $\begin{array}{l}\text { Cement, M-Sand, aggregates, } \\
\text { water, admixtures }\end{array}$ \\
\hline Grade of concrete & M 20, M25, M30 \\
\hline Mix proportion & $1: 3.5: 5,1: 3: 4.5,1: 2.5: 3.91$ \\
\hline Supplementary material (kg) & $80,70,40$ \\
\hline \multicolumn{2}{|c|}{ 1.3 Transit: mileage $(\mathrm{km} / \mathrm{l})$, distance $(\mathrm{km})$, capacity of truck $(\mathrm{t})$} \\
\hline Cement & $5.2,225,25$ \\
\hline M-Sand & $2.5,20,25$ \\
\hline Aggregate & $2.5,20,25$ \\
\hline Supplementary material & $5.2,225,25$ \\
\hline \multicolumn{2}{|l|}{ 1.4 Maintenance } \\
\hline Mode of cleaning & Human labor \\
\hline $\begin{array}{l}\text { Process of cleaning plant and } \\
\text { wastewater disposal }\end{array}$ & Water used, deposed nearby \\
\hline \multicolumn{2}{|l|}{ 1.5 Waste management } \\
\hline $\begin{array}{l}\text { Disposal of waste generated in the } \\
\text { plant }\end{array}$ & Fresh concrete-reused \\
\hline \multicolumn{2}{|l|}{ 1.6 Human Laborers } \\
\hline \multirow[t]{5}{*}{ Per Day (8 h) } & Engineers: 8 \\
\hline & Unskilled: 5 \\
\hline & Technical: 5 \\
\hline & Drivers: 10 \\
\hline & For concrete pumping works: 20 \\
\hline \multicolumn{2}{|l|}{ 2. Site } \\
\hline \multicolumn{2}{|l|}{ 2.1 General } \\
\hline Location of building & Coimbatore, Tamil Nadu India \\
\hline Type of building & Commercial, RCC \\
\hline Number of floors & 3 \\
\hline Floor area of one level & $307 \mathrm{~m}^{2}$ \\
\hline \multicolumn{2}{|c|}{ 2.2 Transit: mileage $(\mathrm{km} / \mathrm{l})$, distance $(\mathrm{km})$, capacity of truck $\left(\mathrm{m}^{3}\right)$} \\
\hline Concrete & $2,6,8$ \\
\hline \multicolumn{2}{|l|}{ 2.3 Materials } \\
\hline Steel & $32 \mathrm{t}$ \\
\hline Brick & $62,622 \times 1$ \\
\hline Mortar mix & $1: 5$ \\
\hline \multirow[t]{2}{*}{ Finish } & Sand: $692.8 \mathrm{~kg} / \mathrm{m}^{3}$ \\
\hline & Cement: $92 \mathrm{~kg} / \mathrm{m}^{3}$ \\
\hline \multicolumn{2}{|l|}{ 2.4 Construction process } \\
\hline Pumping & $0.41 / \mathrm{m}^{3}$ \\
\hline Compaction & $0.41 / \mathrm{m}^{3}$ \\
\hline 2.5 Waste management & \\
\hline
\end{tabular}

Table 16 continued

\begin{tabular}{ll}
\hline $\begin{array}{l}\text { Disposal of waste generated in } \\
\text { site and its disposal }\end{array}$ & Steel: sold as scrap \\
2.6 Human labor (per $8 \mathrm{~h}$ shift) & \\
Laborers used in site & $20 \times 1(8 \mathrm{~h})$ \\
Duration of work & 140 days \\
\hline
\end{tabular}

\section{References}

1. P. Nejat, F. Jomehzadeh, M.M. Taheri, M. Gohari, M.Z.A. Majid, A global review of energy consumption, $\mathrm{CO}_{2}$ emissions and policy in the residential sector (with an overview of the top ten $\mathrm{CO}_{2}$ emitting countries). Renew. Sustain. Energy Rev. 43, 843-862 (2015)

2. India Energy Outlook, World Energy Outlook Special Report2015, International Energy Agency

3. K.I. Praseeda, B.V. Reddy, M. Mani, Embodied energy assessment of building materials in India using process and inputoutput analysis. Energy Build. 86, 677-686 (2015)

4. Z. Zhang, X. Wu, X. Yang, Y. Zhu, BEPAS-a life cycle building environmental performance assessment model. Build. Environ. 41(5), 669-675 (2006)

5. M.K. Dixit, C.H. Culp, J.L. Fernandez-Solis, Embodied energy of construction materials: integrating human and capital energy into an IO-based hybrid model. Energy Build. 151, 107-120 (2015)

6. A. Rauf, R.H. Crawford, Building service life and its effect on the life cycle embodied energy of buildings. Energy 79, 140-148 (2015)

7. I. Sartori, A.G. Hestnes, Energy use in the life cycle of conventional and low-energy buildings: a review article. Energy Build. 39(3), 249-257 (2007)

8. A. Debnath, S.V. Singh, Y.P. Singh, Comparative assessment of energy requirements for different types of residential buildings in India. Energy Build. 23(2), 141-146 (1995)

9. B.V. Reddy, K.S. Jagadish, Embodied energy of common and alternative building materials and technologies. Energy Build. 35(2), 129-137 (2003)

10. B.V. Venkatarama Reddy, Sustainable materials for low carbon buildings. Int. J. Low Carbon Technol. 4(3), 175-181 (2009)

11. S.U. Menon, K.B. Anand, A.K. Sharma, Performance evaluation of alkali-activated coal-ash aggregate in concrete, in Proceedings of the Institution of Civil Engineers-Waste and Resource Management, vol 171, no. 1 (Thomas Telford Ltd, 2018), pp. 4-13

12. M.K. Dixit, J.L. Fernández-Solís, S. Lavy, C.H. Culp, Identification of parameters for embodied energy measurement: a literature review. Energy Build. 42(8), 1238-1247 (2010)

13. J. Macias, L. Iturburu, C. Rodriguez, D. Agdas, A. Boero, G. Soriano, Embodied and operational energy assessment of different construction methods employed on social interest dwellings in Ecuador. Energy Build. 151, 107-120 (2017)

14. K.I. Praseeda, B.V. Venkatarama Reddy, M. Mani, Embodied and operational energy of urban residential buildings in India. Energy Build. 110, 211-219 (2016)

15. D. Bansal, R. Singh, R.L. Sawhney, Effect of construction materials on embodied energy and cost of buildings-a case study of residential houses in India up to $60 \mathrm{~m}^{2}$ of plinth area. Energy Build. 69, 260-266 (2014) 
16. T. Ramesh, R. Prakash, K.K. Shukla, Life cycle energy analysis of a multifamily residential house: a case study in Indian context. Open J. Energy Effic. 2(01), 34-41 (2013)

17. L. Aye, T. Ngo, R.H. Crawford, R. Gammampila, P. Mendis, Life cycle greenhouse gas emissions and energy analysis of prefabricated reusable building modules. Energy Build. 47, 159-168 (2012)

18. Y. Jiao, C.R. Lloyd, S.J. Wakes, The relationship between total embodied energy and cost of commercial buildings. Energy Build. 52, 20-27 (2012)

19. Y. Chang, R.J. Ries, S. Lei, The embodied energy and emissions of a high-rise education building: a quantification using processbased hybrid life cycle inventory model. Energy Build. 55, 790-798 (2012)

20. J. Monahan, J.C. Powell, An embodied carbon and energy analysis of modern methods of construction in housing: a case study using a lifecycle assessment framework. Energy Build. 43(1), 179-188 (2011)

21. K. Adalberth, Energy use during the life cycle of single-unit dwellings: examples. Build. Environ. 32(4), 321-329 (1997)

22. B. Lopez-Mesa, A. Pitarch, A. Tomas, T. Gallego, Comparison of environmental impacts of building structures within situ cast floors and with precast concrete floors. Build. Environ. 44(4), 699-712 (2009)

23. Y.H. Dong, L. Jaillon, P. Chu, C.S. Poon, Comparing carbon emissions of precast and cast-in situ construction methods-a case study of high-rise private building. Constr. Build. Mater. 99, 39-53 (2015)

24. C. Mao, Q. Shen, L. Shen, L. Tang, Comparative study of greenhouse gas emissions between off-site prefabrication and conventional construction methods: two case studies of residential projects. Energy Build. 66, 165-176 (2013)

25. R. Smith, S. Narayanamurthy, Prefabrication in developing countries: a case study of India, in Wood Structures Symposium (2009), pp. 48-53

26. R.M. Pulselli, E. Simoncini, N. Marchettini, Energy and energy based cost-benefit evaluation of building envelopes relative to geographical location and climate. Build. Environ. 44(5), 920-928 (2009)

27. Y.L. Langston, C. Langston, Building energy and cost performance: an analysis of thirty Melbourne case studies. Constr. Econ. Build. 7(1), 1-18 (2012)

28. FAO, Human Energy Requirements; Report of a Joint FAO/ WHO/UNU Expert Consultation; Food and Agriculture Organization of the United Nations, Rome, 17-24 Oct 2001

Publisher's Note Springer Nature remains neutral with regard to jurisdictional claims in published maps and institutional affiliations. 